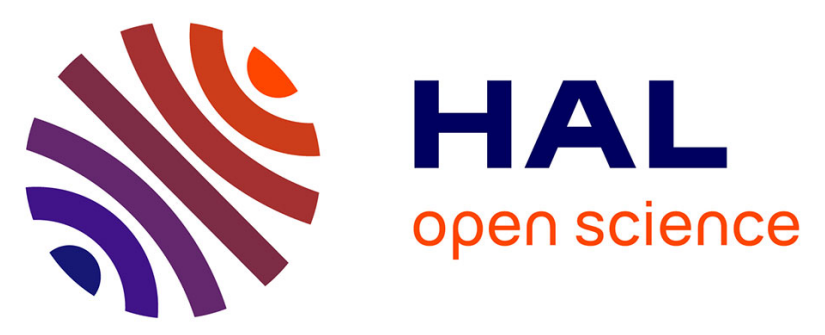

\title{
Exploring the Best Practices for Co-innovation in Industry and Academy Collaboration - Four Practical Case Examples
}

Katri Valkokari, Pasi Valkokari, Tuija Rantala, Jutta Nyblom

\section{To cite this version:}

Katri Valkokari, Pasi Valkokari, Tuija Rantala, Jutta Nyblom. Exploring the Best Practices for Coinnovation in Industry and Academy Collaboration - Four Practical Case Examples. 22nd Working Conference on Virtual Enterprises (PRO-VE 2021), Nov 2021, Saint-Etienne, France. pp.749-758, 10.1007/978-3-030-85969-5_71. emse-03350284

\section{HAL Id: emse-03350284 \\ https://hal-emse.ccsd.cnrs.fr/emse-03350284}

Submitted on 25 Nov 2021

HAL is a multi-disciplinary open access archive for the deposit and dissemination of scientific research documents, whether they are published or not. The documents may come from teaching and research institutions in France or abroad, or from public or private research centers.
L'archive ouverte pluridisciplinaire HAL, est destinée au dépôt et à la diffusion de documents scientifiques de niveau recherche, publiés ou non, émanant des établissements d'enseignement et de recherche français ou étrangers, des laboratoires publics ou privés. 
Valkokari K., Valkokari P., Rantala T., Nyblom J. (2021) Exploring the Best Practices for Co-innovation in Industry and Academy Collaboration - Four Practical Case Examples. In: Camarinha-Matos L.M., Boucher X., Afsarmanesh H. (eds) Smart and Sustainable Collaborative Networks 4.0. PRO-VE 2021. IFIP Advances in Information and Communication Technology, vol 629. Springer, Cham. https://doi.org/10.1007/978-3030-85969-5_71

\title{
Exploring the Best Practices for Co-innovation in Industry and Academy Collaboration - Four Practical Case Examples
}

\author{
Katri Valkokari, Pasi Valkokari, Tuija Rantala and Jutta Nyblom \\ VTT, Technical Research Centre of Finland, PL1306, FI-33101 Tampere, Finland \\ \{Katri.Valkokari, Pasi.Valkokari, Tuija Rantala and Jutta Nyblom\}@vtt.fi
}

\begin{abstract}
Managing the continuation of an innovation funnel from scientific knowledge to commercialisation in a collaborative setting is a challenging task. The purpose of this paper is to explore the best practices for governing the collaborative industry-academy innovation process. As an outcome, the paper presents best practices as well as the weaknesses and strengths of three mechanisms of collaborative innovation. The mechanisms are: (1) having a strong vision and enabling technologies, (2) orchestration by a globally operating core company and (3) regional clusters facilitated by public actors.
\end{abstract}

Keywords: practices, industry-academy collaboration, co-innovation

\section{Introduction}

In a modern innovation, hackathons, innovation laboratories, innovation spaces, living labs, maker spaces and fab labs have been mentioned as necessities for successful innovation. In other words, innovation is based on collaboration between a variety of actors [1];[2] - including practitioners from industry and researchers representing an academy. The fluent management of the innovation funnel, from research ideas and knowledge towards commercialisation in a collaborative business setting, is a challenging task. The concrete ways by which industrial actors are seeking improvements and renewal or benchmarking are often limited by organisations in their industry sector [3]. Recently, B2B research is increasingly focusing on the broader collaborative settings of actors connected through the various technological systems and platforms [4].

In this study, we follow the research stream of collaborative networks [5] and aim to look beyond traditional organisational boundaries. Although the discussion on collaborative and open innovation has been active in recent years and, for instance, Davey et al, [6] presented a wide study of practical case examples of industry-academy collaboration, longitudinal studies are still scarce. Therefore, instead of zooming out, we seek mechanisms for successful collaborative practices between industry and academia. The purpose of this paper is to explore the best practices for industryacademy innovation collaboration. This is done by analysing four different ecosystemic innovation cases in the context of manufacturing and construction domains. 
The paper builds on a comparison between three mechanisms of co-evolution within the collaborative innovation funnel. All the cases aim to build a novel competitive advantage through systemic changes to current networks as disruption is driven by servitisation, sustainability and digitalisation. This requires collaborative innovation, crossing the borders of industrial sectors.

\section{The Theoretical Background}

Although in textbooks the process of innovation is often simplified into a linear process [7], in practice it is seldom linear, even in the case of intra-firm innovation. In a collaborative setting, such as industry-academy co-innovation, it can really be a multidimensional, complex process. Since Chesbrough introduced the concept of open innovation in 2003 [8], the related literature has tried to understand and model innovation practices that go beyond the boundaries of a single firm [1];[2]. Such innovation ecosystems can be seen as a special type of collaborative network [9]. In this paper our aim is to explore innovation that is crossing industrial boundaries [3].

Both the collaborative innovation ecosystems as a whole and their components constantly evolve. A successful innovation ecosystem is the result of a process of continuous evolution, which is often a long, complex and slow process, and its development may have different stages of maturity [10]. Beneficial collaboration requires that the actors of the ecosystem are willing to share the knowledge that is required for the co-innovation between ecosystem actors and are capable of doing so. Thus, the cross-industry collaborative setting includes additional challenges due to the different backgrounds and cultures of the actors involved [11]. This ecosystem orchestration should be handled in such a way that the created breeding environment and joint co-innovation processes remain attractive to all actors.

There are different mechanisms that enable co-innovation between multiple actors. One mechanism is that an ecosystem can be an artefact when there is an actor that has a strategic intention to design ecosystemic collaboration [12]. Such an actor can be a keystone company [13]; a public or research organisation may have a strategical intention to create an ecosystem. Another mechanism is that the ecosystem can be formed autonomously when a sufficient number of actors have aligned strategic interests. The latter mechanism is often accompanied by hype around a certain topic which encourages several actors to gather together or it can be based on the geographical proximity of the actors that operate within the same cluster [14]; [15].

Based on the earlier research and practical work with ecosystems summarised above, in our study we have identified three main mechanisms (see Figure 1) that follow: (1) driven by a shared vision and enabling technologies, (2) orchestration by a globally operating core company and (3) regional clusters facilitated by public actors. Each of these mechanisms has its strengths and weaknesses as the roles of the involved actors vary. Cities and local development agencies often play a key role in ecosystems, building on regional strengths. Ecosystems associated with companies that are strong industrial drivers are closely integrated into the international business environment and operations. Ecosystems based on the shared vision enable major transitions even though the process of transforming the visions into practical development work may be slow 
at first. Ecosystems relying on a strong national vision and a development agenda may encounter fragmented decision-making in ministries and challenges related to continuity in commitment to the vision

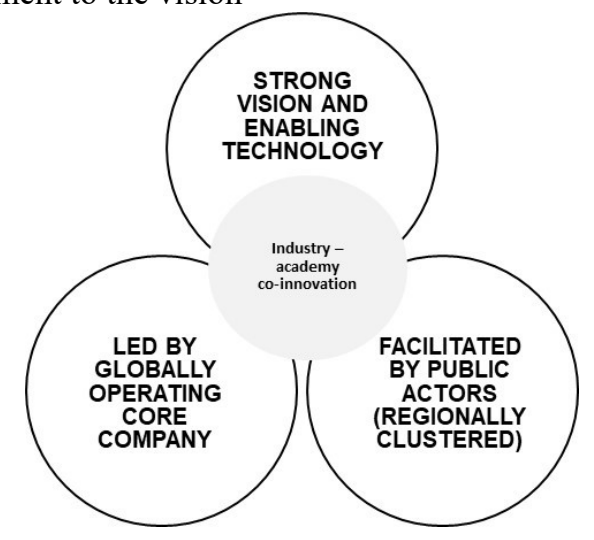

Fig. 1. The three mechanisms of innovation ecosystems.

Ensuring sufficient renewal may present a challenge to ecosystems driven by strong industrial leader companies or based on regional clustered actors. In particular, wellestablished companies may be reluctant to give up their competitive advantages and business operating models.

\section{Methodology: A Case Study}

The goal of the paper is to explore mechanisms enabling industry-academy collaboration within the co-innovation process in a multi-actor setting. We aim to create new understanding of the vital role of shared processes in enhancing co-innovation and how the contributions of the involved industry and academy actors take shape. Accordingly, we formulate the following research question: What are the pros and cons of the different mechanisms of ecosystems that are used in coordinating industryacademy collaborative innovation?

The selection of four case ecosystems was made according to guidelines for case research [16]. In the cases, researchers had access to the industry-academy collaboration in four innovation ecosystem settings, and the selected cases were both comparable and complementary. Table 1 summarises the basic information of these four cases. The level of analysis was industry-academy collaboration within the ecosystems.

The first innovation ecosystem, 'Case A', offers an open innovation marketplace to match make the challenges of the Finnish forest industry and the innovative offerings of the Finnish IT industry with the innovations catalysed by research. The second innovation ecosystem, 'Case B', connects Finnish manufacturing factories, research institutes and SME-sized IoT/IT companies via agile co-creation and experience 
sharing within real-world production environments. The third innovation ecosystem, 'Case C', is developing a business ecosystem and a platform to promote the development of intelligent data-based services in the context of smart buildings. Finally, the fourth innovation ecosystem, 'Case D', aims to boost the performance of Finnish manufacturing SMEs and accelerate their sustainable digitalisation journey. Currently, it has a regional focus as the involved actors are geographically quite closely situated.

Table 1. A summary of the case ecosystems.

\begin{tabular}{|c|c|c|}
\hline Case & Number of participants & Industry sectors \\
\hline Case A & $\begin{array}{l}\text { Industry: } 12 \text { large and } 9 \text { small companies, } \\
\text { Academy: } 2 \text { universities and } 1 \text { Research and } \\
\text { Technology Organisation (RTO) }\end{array}$ & Forest, ICT, design \\
\hline Case B & $\begin{array}{l}\text { Industry: } 8 \text { large companies } \\
\text { Academy: } 3 \text { universities, } 1 \text { RTO }\end{array}$ & Manufacturing, ICT \\
\hline Case C & $\begin{array}{l}\text { Industry: } 5 \text { large and } 1 \text { small company, } \\
\text { Academy: } 1 \text { RTO }\end{array}$ & $\begin{array}{l}\text { Construction, services, } \\
\text { ICT }\end{array}$ \\
\hline Case D & $\begin{array}{l}\text { Academy and intermediators: } 9 \text { research and } \\
\text { education organisations and } 5 \text { public actors }\end{array}$ & Smart manufacturing \\
\hline
\end{tabular}

The data utilised in this study included, for example, participatory observations on ecosystem activity in numerous meetings and workshops, their results, different kinds of project plans and documents, discussions on on-line tools, interviews and facilitated on-line discussions conducted as part of industry-academy collaboration. In each case, approximately 20 researchers and over 20 practitioners participated in industryacademy collaboration activities. The material covers the time period from the initiation of collaboration to two and half years from then in Case A, three years ahead in Case $\mathrm{B}$, one and half year ahead in Case $\mathrm{C}$ and approximately one year ahead in Case D.

\section{Findings: The Pros and Cons of the Three Mechanisms}

The analyses of empirical data from industry-academy collaboration practices were made based on comparison between the three mechanisms of co-evolution (see Figure 1) within the collaborative innovation funnel. Although the four ecosystems have different modes of operation, similarities were also found. In this section we will first present the operation model of each innovation ecosystem and the key activities in industry-academy collaboration.

The vision-led Case A ecosystem operates with three levels of industry-academy collaboration. The long-term vision track is for solving systematic-level industry challenges and affecting systematic change in the related industry. This track includes, for example, vision creation and related insights, and it is led by research. Thus, design thinking and agile methods enable the industry-driven co-creation track to solve use cases and create a joint offering. The forest industry companies have stated that 'we are transforming the way industry works'. Company-driven collaboration is for scaling up and commercialising the ideas for international markets. The broad number of company participants, as well as their different backgrounds, caused some challenges for 
ecosystem co-operation, and therefore the ecosystem's operation model continuously evolves with the participants.

Table 2. Case A: Key activities in industry-academy collaboration

\begin{tabular}{llll}
\hline Roles & Company-driven & Vision-led & $\begin{array}{l}\text { Public/region- } \\
\text { facilitated }\end{array}$ \\
\hline Industry & $\begin{array}{l}\text { Industrial companies as } \\
\text { use case owners as well }\end{array}$ & $\begin{array}{l}\text { The companies are actively } \\
\text { involved in vision building }\end{array}$ \\
as IT companies as & & \\
solvers & $\begin{array}{l}\text { The identification of new } \\
\text { companies } \\
\text { matchmaking }\end{array}$ & and & $\begin{array}{l}\text { Long-term research work that Building linkages to } \\
\text { connects the industrial use the national agenda } \\
\text { cases and the vision for through the funding } \\
\text { industry renewal }\end{array}$ \\
\hline
\end{tabular}

Similarly to Case A, the Case B ecosystem is vision-led and operates through sprints and by creating proofs of concept (PoCs) for jointly recognised grand challenges. The participating eight industry actors provide their factories as innovation platforms and are involved in defining the requirements for the different PoCs. Anyhow, the research organisation also has an active role in describing the requirements as well as identifying possible SMEs to provide solutions. Together, the ecosystem steers sprints and PoCs, and SMEs demonstrate their existing solutions. In addition, ecosystem actors (especially the academies) assist SMEs in scaling up within the factories involved at the ecosystem, commercialising the $\mathrm{PoC}$ and disseminating the results in, for example, ecosystem workshops, scientific papers and blogs. Anyhow, the SMEs providing the solutions to PoCs are not members of the ecosystem; instead, they have a role as subcontractors.

Table 3. Case B: The key activities in industry-academy collaboration

\begin{tabular}{|c|c|c|c|}
\hline Roles & Company-driven & Vision-led & $\begin{array}{l}\text { Public/region- } \\
\text { facilitated }\end{array}$ \\
\hline Industry & $\begin{array}{l}\text { Factories as innovation } \\
\text { platforms, benchmarking } \\
\text { between them }\end{array}$ & $\begin{array}{l}\text { Leading research work around } \\
\text { specific grand challenges; the } \\
\text { vision is divided into practical, } \\
\text { well-defined PoCs }\end{array}$ & \\
\hline Academy & $\begin{array}{l}\text { Matchmaking and SME } \\
\text { engagement }\end{array}$ & $\begin{array}{l}\text { Participating research } \\
\begin{array}{l}\text { around work } \\
\text { challenges }\end{array}\end{array}$ & $\begin{array}{l}\text { Research institutes } \\
\text { worked together } \\
\text { with a public } \\
\text { funding body to } \\
\text { boost the launch of } \\
\text { the project }\end{array}$ \\
\hline
\end{tabular}

The Case $\mathbf{C}$ is a company-driven ecosystem in which all the involved companies share the vision of building a platform. The ecosystem has a leader company which has initiated the ecosystem's co-operation and is providing the starting point for the strategic agenda and the ecosystem's paths to international markets. Through hackathons, the ecosystem actors have opened the identified research agenda to SMEs. 
The aim of the hackathons is to open new business opportunities for these SMEs as subcontractors. The ecosystem has also involved a venture client alliance that has the responsibility of organising the industry hacks. The industry-academy collaboration is based on the cross-functional teams, and this ecosystem also organises the shared problem solving in sprints.

Table 4. Case C: The key activities in industry-academy collaboration

\begin{tabular}{llllll}
\hline Roles & Company-driven & Visio-led & \multicolumn{1}{c}{$\begin{array}{l}\text { Public/region- } \\
\text { facilitated }\end{array}$} \\
\hline Industry & $\begin{array}{l}\text { Companies initiated the } \\
\text { collaboration } \\
\text { actively manage it and together by } 7\end{array}$ core \\
Academy & $\begin{array}{l}\text { Supports the company- } \\
\text { initiated co-operation }\end{array}$ & $\begin{array}{l}\text { Participating research work } \\
\text { around specific topics }\end{array}$ & \\
\hline
\end{tabular}

The Case D ecosystem is based on the national agenda of smart manufacturing. It is strongly led by an academy and, on the other hand, it aims to be a roof ecosystem with several different horizontal and vertical ecosystems and networks. This national initiative improves the Finnish industry's performance and sustainable growth through innovation and knowledge. Currently, it is a quite loosely coupled network of research and education organisations. The engagement of industry actors is based on the involved organisations' independent networks and research projects.

Table 5. Case D: The key activities in industry-academy collaboration.

\begin{tabular}{|c|c|c|c|}
\hline Roles & Company-driven & Vision-led & $\begin{array}{l}\text { Public/region- } \\
\text { faclitated }\end{array}$ \\
\hline Industry & $\begin{array}{l}\text { Through involvement, } \\
\text { large companies aim to } \\
\text { guide research activities }\end{array}$ & $\begin{array}{l}\text { Companies' interests are } \\
\text { loosely coupled to the } \\
\text { national agenda }\end{array}$ & \\
\hline Academy & $\begin{array}{l}\text { The development of the } \\
\text { capabilities of SMEs } \\
\text { through research and } \\
\text { education }\end{array}$ & $\begin{array}{l}\text { Bridging the national } \\
\text { agenda and the research } \\
\text { portfolio }\end{array}$ & $\begin{array}{l}\text { The strong national } \\
\text { agenda guides the } \\
\text { ecosystem's work and } \\
\text { linkages to } \\
\text { international research } \\
\text { networks }\end{array}$ \\
\hline
\end{tabular}

The empirical analyses of four cases showed that each of the three identified mechanisms has its strengths and weaknesses. These pros and cons are summarised in Table 6.

National agendas, as well as local development agencies and cities, often play a key role in ecosystems, building on regional strengths. It can be stated that in Case D, the research organisation has an exceptionally strong role in building the ecosystem. This was partially based on the strategic research agenda of this organisation. Thus, rather broad ecosystems relying on a strong national vision and a development agenda may encounter the fragmented decision-making of different authorities and challenges related to continuity in commitment to the vision. 
Table 6. A summary of the pros and cons of the three mechanisms.

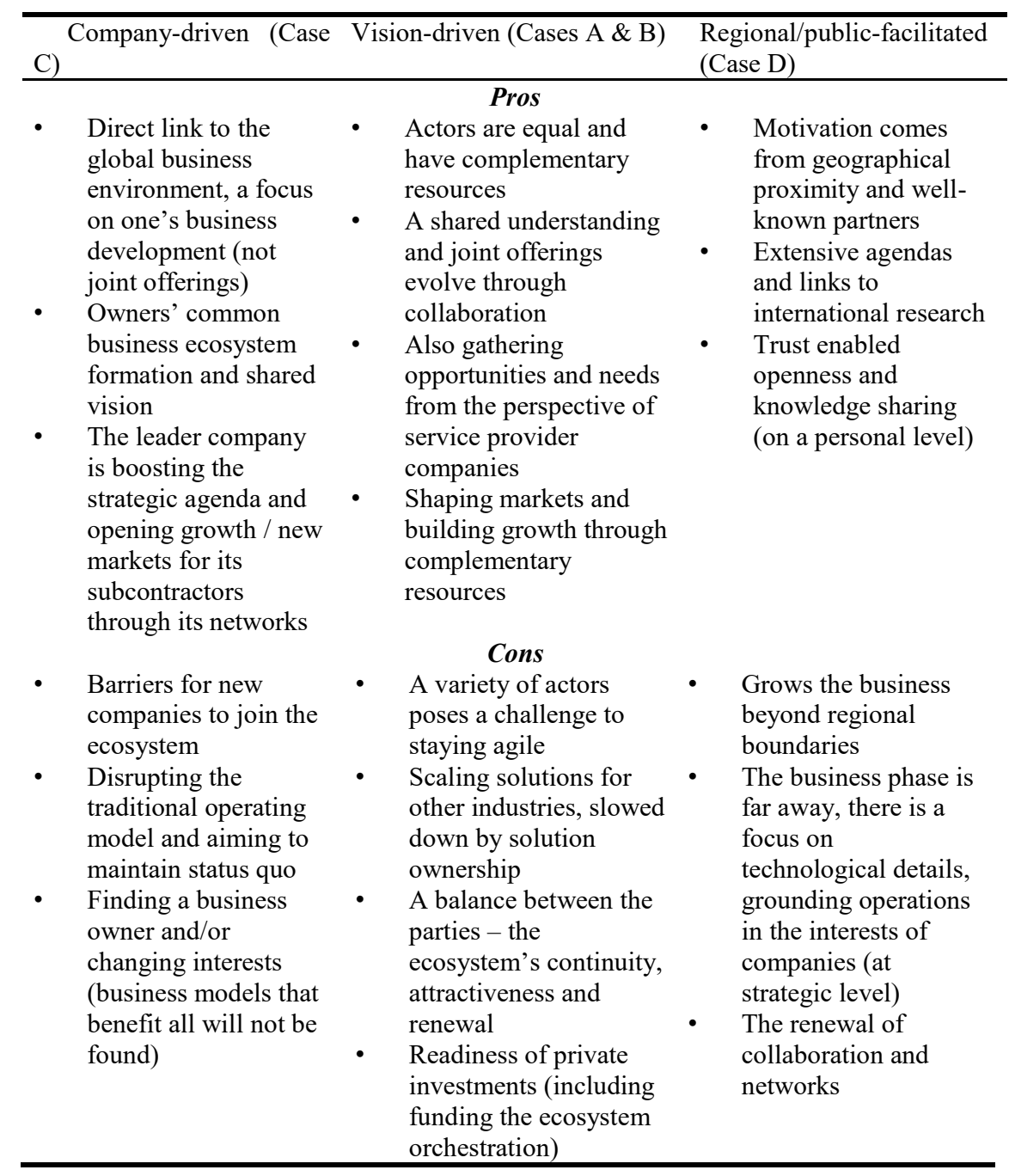

Ecosystems based on the vision enable major transitions even though the process of transforming the visions into practical development work may be slow at first. Both Case A and B provide empirical evidence that it is important to boost collaboration between the companies who have different competencies and that academies could have an even more active role in matchmaking the companies as well as in challenging their thinking based on research results and novel understanding. Digitalisation has been one of the driving forces for novel collaboration models, but concurrently, it also requires cultural change towards more agile operation models as well as cross-industrial collaboration. 
Ecosystems associated with strong industrial driver companies are closely integrated into the international business environment and operations. In Case $\mathrm{C}$, all the six case companies involved share a vision for future business opportunities based around a platform, although they would have different roles and business models. Based on the different roles, the six industry companies also had different ecosystem strategies, which caused some conflicting interest. Therefore, ensuring sufficient renewal may present a challenge to ecosystems driven by strong industrial leader companies. In order to avoid this barrier, the involved research organisation had a role as an ecosystem project coordinator.

Based on the pros and cons analyses of the three mechanisms, we have integrated the best practices for industry-academy collaboration as a process integrating shortand long-term needs and the different interests of the actors involved. This process for industry-academy collaboration (see Figure 2) aims to optimise the value of research investment with the three interconnected R\&D\&I tracks.

First, within the research-driven long-term vision track, novel research results support industry's systemic long-term challenge to solve and support companies in directing future strategic competitive-edge building. Then, the industry challengedriven idea co-creation track supports co-innovation in order to solve common concrete industry problems with relevant research and to create a business impact in the shorter term. Finally, the industry-owned confidential project track boosts the scaling up and out of the results gained through collaboration.

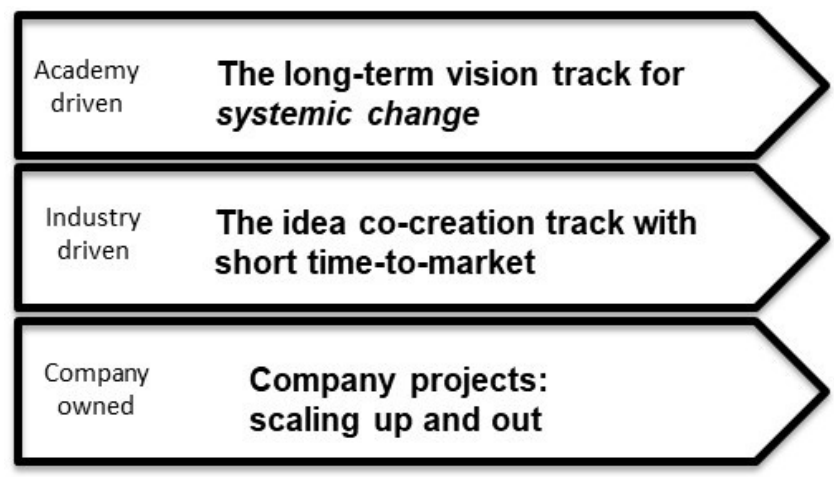

Fig. 2. The industry-academy operation mode.

Furthermore, the longitudinal observations of ecosystem cases also indicated that different phases of the ecosystem lifecycle require different operations models. Especially at the beginning, the role of public actors, as well as the role of public funding, was highlighted. When the collaboration proceeds closer to business operations, it is natural that the role of companies is crucial in order to boost the emergence of business ecosystems and networks. 


\section{Conclusions}

In order to identify the best practices for industry-academy collaboration, we have analysed four cases. Our empirical cases provide practical implications, although every collaboration within an innovation funnel is heterogeneous with their specialties. Therefore, it is important to understand how a shared aim, structure of collaboration and variety of actors influence best practices. As a starting point, it should be noted that the practices and processes of co-innovation need to be co-created with the involved actors. In other words, they cannot be brought from one collaborative setting to another without mutual understanding about their meaning. Furthermore, the variety of actors is an important factor for the diversity of the ecosystem, which will then bring challenges for coordination. Different interests, as well as different expectations and mind-sets, may even hinder the collaboration. As for the managerial implications of this study, the three mechanisms studied may support the identification of the different perspectives of the involved actors and the concretisation of their roles in co-innovation ecosystems.

Although the literature of collaborative networks provides an excellent baseline for understanding industry-academy collaboration, there is still room for fruitful research. The evaluation of the three mechanisms was done in four innovation ecosystems within their building base; the co-evolution within ecosystems may take years. Therefore, one obvious avenue for further research would be the follow-up of these ecosystems. Then, in order to test the three mechanisms and their impacts on a larger scale, another important dimension for future research would be based on a quantitative approach.

Acknowledgments. The authors would like to thank all the parties of the case ecosystems for their support of this study. This study has been done as a part of the funding that the Finnish Government gave to VTT Technical Research Centre of Finland in order to promote the digitalisation and competitiveness of Finnish manufacturing industry in a post-Covid world.

\section{References}

[1] Lee, S., Olson, S. M., Trimi, D. L.: Co-Innovation: Convergenomics, collaboration, and co-creation for organizational values. Manag. Decis., vol. 50, no. 5, pp. 817-831, (2012).

[2] Bogers, M. et al.: The open innovation research landscape : established perspectives and emerging themes across different levels of analysis. Ind. Innov., vol. 2716, pp. 1-33, (2016).

[3] Nuutinen, M., Palomäki, K., Valkokari, K.: Understanding industrial service ecosystems as a mechanism for solving systemic challenges, in Forum on Markets and Marketing 2020: Institutions, Service Ecosystems and Emergence, Aalto University (2020).

[4] Aarikka-Stenroos, L., Ritala, P.: Network management in the era of ecosystems: Systematic review and management framework. Ind. Mark. Manag., vol. 67, pp. 23-36, (2017).

[5] Camarinha-Matos, L., Fornasiero, X., Afsarmanesh, H.: Collaborative networks as a 
core enabler of Industry 4.0, in Collaboration in a Data-Rich World. PRO-VE 2017. IFIP AICT, vol 506. Springer, Cham. https://doi.org/10.1007/978-3-31965151-4 1

[6] Davey, T., Deery, M., Winters, C., Van Der Sijde, P., Kusio, T., Rodriquez, S.: 30 best case studies of good practice in the area of UBC within Europe. (2009).

[7] Cooper, R., Edgett, S.: Lean, Rapid and Profitable New Product Development. Ancaster, ON: Product Development Institute, (2005).

[8] Chesbrough, H.: Open Innovation: The New Imperative for Creating and Profiting from Technology. Boston: Harvard Business School Press. (2003).

[9] Rabelo, R., Bernus, P., Romero, D.: Innovation ecosystems: A collaborative networks perspective, in Risks and Resilience of Collaborative Networks. Springer, (2015).

[10] Bittencourt, B. A., Santos, D. A. G., Mignoni, J.: Resource orchestration in innovation ecosystems: a comparative study between innovation ecosystems at different stages of development. Int. Hournal Innov., vol. 9, no. 1, pp. 108-130, (2021).

[11] Valkokari, K., Valkokari P., Kortelainen, H., Nyblom, J.: Building business impacts of an industry 4.0 ecosystem through collaborative network settings between IT and forest companies. IFIP Adv. Inf. Commun. Technol., vol. 598, pp. 463-474, (2020).

[12] Tsujimoto, M., Kajikawa, Y. Tomita, J., Matsumoto, Y.: A review of the ecosystem concept: Towards coherent ecosystem design. Technol. Forecast. Soc. Change, vol. 136, pp. 49-58, (2018).

[13] Iansiti M., Levien, R.: Strategy as ecology. Harv. Bus. Rev., vol. 82, no. 3, (2004).

[14] Valkokari, K.: Business, innovation, and knowledge ecosystems: How they differ and how to survive and thrive within them. Technol. Innov. Manag. Rev., vol. 5, no. 8, pp. 17-24, (2015).

[15] Clarysse, B. Wright, M., Bruneel, J., Mahajan, A.: Creating value in ecosystems: Crossing the chasm between knowledge and business ecosystems. Res. Policy, vol. 43, no. 7, pp. 1164-1176, (2014).

[16] Eisenhardt, K. M.: Building theories from case study research, Acad. Manag. Rev. vol. 14, pp. 532-550, (1989). 